Original scientific article/Izvirni znanstveni članek

\title{
Women's experience and attitudes towards menopause and health: descriptive research \author{
opisna raziskava
} \\ Stališča in izkušnje žensk z menopavzalnim obdobjem in njihov odnos do zdravja:
}

Jožefa Gregorin, Jožica Ramšak Pajk

Key words: symptoms of menopause; lifestyle; nurse; primary health care

Ključne besede: menopavzalne težave; življenjski slog; medicinska sestra; primarno zdravstveno varstvo

Jožefa Gregorin, RN; Health Care Institution Revita, Peričeva 31, Ljubljana, Slovenia

Correspondence e-mail/ Kontaktni e-naslov: jozigregorin@gmail.com

Senior Lecturer Jožica Ramšak Pajk, MSc, BSc, RN; Community Health Centre Ljubljana - Bežigrad, Kržičeva 10, Ljubljana and Faculty of Health Care Jesenice, Spodnji Plavž 3, 4270 Jesenice, Slovenia

The article is based on the diploma work of Jožefa Gregorin Menopausal women and their attitude towards health (2016)./Članek je nastal na osnovi diplomskega dela Jožefe Gregorin Ženska v menopavzi in odnos do zdravja (2016).

Received/Prejeto: 10. 9. 2016 Accepted/Sprejeto: 15. 11. 2016

\begin{abstract}
Introduction: The physiological changes in hormonal levels occurring during perimenopause and postmenopause may affect the health of women. The purpose of the research was to explore the views and attitudes of women of this stage towards menopause, health, healthy lifestyle and some aspects of information regarding menopause.

Methods: The study was based on a quantitative and qualitative approach. A semi-structured questionnaire (Cronbach $\alpha=0.813$ ) was used as a research instrument. The open question was interpreted by a qualitative method. A random systematic sample consisted of one hundred female patients, aged 45 to 60 years, attending a private healthcare institution. The survey was conducted in October 2014. The data collected were processed with the software Microsoft Excel and SPSS version 20.0.

Results: The self-reported health status of the respondents was good (57.3\%) or very good $(22.3 \%)$. The most commonly cited symptoms included hot flushes and night sweats $(\bar{x}=2.73)$, sleep problems $(\bar{x}=2.8)$, and mental and physical exhaustion $(\bar{x}=2.70)$. Information from nurses was never sought by $57.6 \%$ and occasionally by $9.8 \%$ of the respondents, although the interviewees expressed the need for more comprehensive information on the subject. The identified subcategories include a positive attitude and self-confidence, support of the environment, consumer health information and healthy lifestyle.

Discussion and conclusion: The research participants have a positive attitude to health, they are aware that there is much they can do to maintain and improve their health. As they also expressed the need to be better informed, the scope of nurses' work in referential out-patient clinics may be extended to menopausal counselling. However, more research on this topic needs to be undertaken.
\end{abstract}

\section{IZVLEČEK}

Uvod: Obdobje perimenopavze in pomenopavze vpliva na zdravje žensk. Namen raziskave je bil raziskati stališča in odnos žensk do tega obdobja, do zdravja in do zdravega življenjskega sloga ter nekatere vidike informiranosti.

Metode: Raziskava temelji na kvantitativnem in kvalitativnem pristopu. Uporabljen je bil delno strukturirani vprašalnik (Cronbach $\alpha=0,813$ ). Opisno vprašanje je bilo interpretirano s kvalitativno metodo. Uporabljen je bil slučajnostni sistematični vzorec stotih pacientk zasebne zdravstvene ustanove, vključitveni kriterij je bil starost od 45 do 60 let. Anketiranje je bilo izvedeno oktobra 2014. Podatki so bili obdelani s programskim orodjem Microsoft Excel in SPSS verzija 20.0.

Rezultati: Anketiranke ocenjujejo svoje zdravje kot dobro (57,3 \%) oziroma zelo dobro (22,3 \%). Največ težav imajo $\mathrm{z}$ vročinskimi oblivi in navali znojenja $(\bar{x}=2,73)$, s spanjem $(\bar{x}=2,8)$ ter s psihično in fizično izčrpanostjo $(\bar{x}=2,70)$. Pri medicinski sestri informacij nikoli ni iskalo $57,6 \%$ vprašanih in nobena od njih pogosto, občasno pa le $9,8 \%$ vprašanih, kljub temu da so anketiranke izpostavile problem premajhne informiranosti. Prepoznane podkategorije so pozitivna naravnanost in samozaupanje, podpora okolice, informiranost in zdrav življenjski slog.

Diskusija in zaključek: Anketiranke imajo pozitiven odnos do zdravja, zavedajo se, da za svoje zdravje lahko veliko storijo same. Izražena je potreba po večji informiranosti, zato je pomembno, da se aktivnosti diplomirane medicinske sestre $\mathrm{v}$ referenčni ambulanti razširijo tudi na področje svetovanja glede menopavze. Potrebne so nadaljnje raziskave na tem področju. 


\section{Introduction}

Health is one of the fundamental elements of our life as it satisfies the need for survival and quality of life (Štern, 2007). In the last decades, several experts have addressed the problems occurring during the perimenopause and postmenopause stages, which may significantly impact on the quality of women's life (Meden-Vrtovec, 2007). Meden-Vrtovec (2007) raises questions about the treatment of menopause women, and whether medical workers are willing to recognise and help alleviate the ensuing physical and psychological symptoms. The changes occur at different levels and are reflected in women' psychological and physical well-being. It is therefore suggested that women are treated as holistic entities, taking into consideration the interdependency and complexity of their parts (Mlakar, 2007). Time period preceding and following menopause is called climacterium. According to Meden-Vrtovec (2002), the phenomenon and duration of climacterium is divided into four stages, i.e. premenopause, when the psychological and somatic changes may be present several years prior to the onset of menopause; perimenopause; menopause, characterised by permanent cessation of menstrual periods; and postmenopause. Hereinafter, the four stages will be referred to as perimenopause (including premenopause and perimenopause) and menopause (including menopause and postmenopause).

Menopause is the time in a woman's life when she is faced with a number of losses, namely, fertility decline, changed physical appearance, change in libido and sex drive, sexual activity and satisfaction. In this period of life, a woman begins to reflect upon the transient nature of her being, as menopause is perceived as a signpost of change, aging or dying (Vigeta, et al., 2012). Menopausal symptoms experienced by women decrease the quality of their life (Borko \& Žegura, 2006, p. 113), but there is increasing evidence that life-style protective factors, such as nutrition and physical activity, have a profound modifying effect on midlife health (Lainščak, et al., 2005; Labrinoudaki, et al., 2013). Marn Radoš and Šćepanović (2014) emphasise the importance of health education about adequate forms of physical activity (e.g. as power walking, running or walking up the stairs, etc.), which is accessible to the entire targeted population, irrespective of their social status. It is of key importance that health professionals explain to women which physical and psychological changes occur during menopause and what they can do to alleviate the symptoms. They may counsel on healthy lifestyle, with special emphasis on nutrition and physical activity (Petkovič, 2007). McCloskey (2012) claims that health workers' knowledge of the concept and the stages of a menopausal transition is still deficient. Cumming and collegues (2015) report that health professionals continue to let their patients down with poor provision of information, inaccurate or wrong information, or lack of access to adequate health care. The cost of this is women living with preventable sequelae associated with the menopausal transition with a consequent adverse impact on health and the health economy. According to Mander (2012), women should be advised on what they should do or avoid in terms of lifestyle and diet to improve their quality of life. Franić (2008) suggests more activities on the primary level of health care, targeted especially to young women in order to prevent problems in later years. The British Menopause Society Council claims that the provision of a simple health check of all women at the age of 45 years would provide an excellent opportunity that would serve as a screening as well as an educational visit at which balanced information about appropriate treatments and lifestyle changes in natural and premature menopause should be given to empower women to make an informed choice (BMSC, 2011).

\section{Aims and objectives}

The aim of the study was to explore the women's views and attitudes towards perimenopause and menopause, health and healthy lifestyle as well some aspects of information related to the issue. The following research questions were set:

- How do women in perimenopause and menopause rate their general health?

- How do women self-assess their menopausal symptoms according to the level of intensity?

- Where do women obtain most information related to menopause and health?

\section{Methods}

A non-experimental descriptive research method was applied.

\section{Description of the research instrument}

A semi-structured questionnaire was used as a research instrument for data collection. The questionnaire was designed on the basis of professional literature review (Borko \& Žegura, 2006; Meden-Vrtovec, 2007; Mlakar, 2007), and partly on the validated Menopause Rating Scale (MRS) developed in Germany (Heinemann, et al., 2004). The original questionnaire was translated into 25 languages, but it was not available in the Slovene language. The questionnaire used in the study was translated from the English language and tested in a pilot study including seven interviewees. It differs from the original version in additional four statements. It is composed of 43 closed-ended, two open-ended, sixteen multiple-choice questions and 27 statements. In 11 questions the MRS was used to evaluate the severity of symptoms/complaints. The score increases point by point with increasing severity of subjectively perceived symptoms in each of the items (severity 0 none, severity 1 - mild, severity 2 - moderate, severity 
3 - severe, severity 4 - very severe). In 16 questions the Likert five-point scale with fixed choice response formats was used to measure the attitudes or opinion statements. Each of the five responses was attributed a numerical value used to measure the attitude under investigation (1-Strongly agree, 2-Agree, 3-Undecided, 4-Disagree, 5-Strongly Disagree). The first part of the questionnaire included nine demographic questions, and the main part enquired about the respondents' attitudes towards menopausal changes and symptoms experienced, the self-assessed lifestyle and bad habits, health and accessibility of information related to menopause. The Cronbach's alpha coefficient for the whole scale was 0.813 , which indicates a high reliability of the instrument (Cencič, 2009).

\section{Description of the research sample}

For the purposes of the study, a random systematic sample was employed. It consisted of 100 women, aged 45-60 years, who had their chosen general practitioner in a private concession clinic, which provides preventive care and curative services for adult population (e.g. diagnostic procedures and treatment of diseases and injuries). DDM 3.0 computer programme was used to select every fifth woman from the alphabet list, satisfying the inclusion criteria $(1: 4$ ratio). The sample consisted of 120 participants, which presents $20 \%$ of the population registered in this clinic. The response rate was $83 \%(n=100)$. The majority of women belonged to the age group of 50-54 years ( $n=41,41.7 \%)$, followed by the age group of $45-49$ years $(n=24,25.7 \%)$ and the age group of 55 years and above $(n=35,32.5 \%)$. Most of the respondents completed university education $(n=38,38.7 \%)$ and only $3(1.2 \%)$ had primary education or less. Most of the respondents were employed $(n=83,81.8 \%)$, and the remaining ones were unemployed $(n=7,10.1 \%)$ or retired $(n=9,7 \%)$. One of the respondents did not answer this question.

The majority of women assessed their socio-economic status as satisfactory $(n=65,63.1 \%), 9(10.4 \%)$ respondents reported that they earn even more than they need, and $25(25.8 \%)$ respondents were not satisfied with their income. One respondent did not answer this question.

According to the stages of menopause as defined by Meden-Vrtovec (2002), the sample consisted of 37 (40.1 \%) women in premenopause or perimenopause and 49 (44.5\%) women in menopause or postmenopause; 14 respondents did not answer this question.

\section{Description of the research procedure and data analysis}

The research was conducted at the primary level of health care, that is, in primary care in the family out-patient clinic. The questionnaires with a request to participate in the study were sent to the selected women's home address in a stamped reply envelope. The purpose of the study was fully explained. The participation was anonymous and voluntary. The study was conducted in accordance with the adopted ethical principles. The sampling took place in October 2014. The data collected were analysed using Microsoft Excel and SPSS version 20.0 (SPSS Inc., Chicago, IL). The sociodemographic data were analysed by descriptive statistics. The frequencies, percentages, arithmetic means and standard deviations were calculated for statistical variables. The t-test was used to determine the statistical significant differences between women in perimenopause and menopause and the Pearson's correlation coefficient was employed to measure the statistical relationship between the two variables. The statistical significance (i.e. the p-value) was set at $p<0.05$.

More than half of the respondents answered the open-ended question. The texts were analysed with a qualitative approach and the meaning from the content of text data was interpreted by a summative content analysis according to the given category of experiencing menopause (Hsieh \& Shannon, 2005). The analysis started with a theory or relevant research findings as guidance for initial codes. It involved counting and comparisons, usually of keywords or phrases, joined in groups and subgroups, followed by the interpretation of the underlying context (Hsieh \& Shannon, 2005).

\section{Results}

The study participants rated their overall health as good $(n=58 \%)$, very good $(n=12 \%)$, fair $(n=22$ $\%)$, poor $(n=3 \%)$ and very poor $(n=2 \%)$. Three respondents did not answer this question. The respondents were requested to report the presence of any chronic non-communicable disease, such as arterial hypertension, diabetes, asthma, etc. Absence of any of the above diseases was reported by $69(70.4 \%)$ interviewees, $1(1.9 \%)$ respondent was not aware of the presence of any disease, and 29 (26.4\%) interviewees suffered from at least one of these diseases.

The study also aimed to establish the respondents' attitudes towards healthy lifestyle. The analysis of survey results shows that $12(12.1 \%)$ women are extremely concerned about their health, 86 (86.9 $\%$ ) claimed that there are many things they can do themselves to maintain or improve their health, 51 $(51.5 \%)$ respondents regularly attend preventive examinations /screening tests, 30 (30.3\%) reported that they try to achieve and maintain a healthy weight, $41(41.4 \%)$ participants reported that they regularly perform physical exercises and maintain their physical fitness, $30(30.3 \%)$ respondents pay particular notice to regular meals and balanced diet. A smaller number of respondents, however, reported insufficient physical 
activity ( $n=35,35.4 \%)$, unhealthy diet and irregular meals $(n=13,13.1 \%)$, and $3(3 \%)$ respondents pay no attention to their health.

The Likert five-point scale with fixed choice response formats was used to measure the attitudes or opinion statements regarding menopause. According to the median values achieved $(M=3)$, it can be concluded that the respondents had some difficulty to accept physical changes associated with aging, they experienced fatigue and exhaustion due to insomnia and they were reluctant to use hormone replacement therapy (HRT) due to possible adverse effects. In part, they also felt liberated by the fact that they no longer need to worry about protection and contraception $(M$ $=3$ ). The menopausal changes, including the inability to bear children, did not affect women's perception of their own femininity $(M=1)$. The results show that the respondents did not agree with the majority of the remaining statements $(M=2)$. The attitudes towards hormone replacement therapy differed among the respondents. Thirteen respondents (13.7\%) were satisfied or very satisfied with the results of the HRT, 46 (48.9 \%) respondents expressed their reservations about HRT for fear of possible adverse effects, and 25 (26\%) respondents believed that their menopauserelated knowledge was insufficient.

The internationally accepted MRS was used to measure the severity of menopausal symptoms over time. The severity of symptoms was evaluated on a five-point self-administered scale. The score increases point by point with increasing severity of subjectively perceived symptoms (from none to very severe). The mean values obtained $(M=3)$ indicate that women most commonly suffered from hot flushes and episodes of sweating, sleep problems (difficulty in falling asleep, difficulty in sleeping through, waking up early), physical and mental exhaustion (general decrease in performance, impaired memory, decrease in concentration, forgetfulness).

Table 1: Comparison of groups of women in perimenopause and menopause regarding the severity of menopause symptoms

Tabela 1: Primerjava skupine žensk v perimenopavzi s skupino žensk v menopavzi glede na jakost menopavzalnih simptomov

\begin{tabular}{|c|c|c|c|c|c|}
\hline $\begin{array}{l}\text { Symptoms/ } \\
\text { Simptomi }\end{array}$ & $\begin{array}{l}\text { Group/ } \\
\text { Skupina }\end{array}$ & $n$ & $\bar{X}$ & $s$ & $p$ \\
\hline \multirow{2}{*}{$\begin{array}{l}\text { Hot flushes, sweating } \\
\text { (episodes of sweating) }\end{array}$} & 1 & 36 & 1.11 & 0.919 & \multirow{2}{*}{0.111} \\
\hline & 2 & 49 & 1.49 & 1.175 & \\
\hline \multirow{2}{*}{$\begin{array}{l}\text { Heart discomfort (unusual awareness of heart } \\
\text { beat, heart skipping, heart racing) }\end{array}$} & 1 & 36 & 0.92 & 0.937 & \multirow{2}{*}{0.418} \\
\hline & 2 & 49 & 1.10 & 1.104 & \\
\hline \multirow{2}{*}{$\begin{array}{l}\text { Sleep problems (difficulty in falling asleep, } \\
\text { difficulty in sleeping through, waking up early) }\end{array}$} & 1 & 36 & 1.61 & 1.076 & \multirow{2}{*}{0.490} \\
\hline & 2 & 48 & 1.79 & 1.254 & \\
\hline \multirow{2}{*}{$\begin{array}{l}\text { Depressive mood (feeling down, sad, on the } \\
\text { verge of tears, lack of drive, mood swings) }\end{array}$} & 1 & 36 & 1.33 & 1.146 & \multirow{2}{*}{0.295} \\
\hline & 2 & 49 & 1.59 & 1.098 & \\
\hline \multirow{2}{*}{$\begin{array}{l}\text { Irritability (feeling nervous, inner tension, } \\
\text { feeling aggressive) }\end{array}$} & 1 & 36 & 1.33 & 1.069 & \multirow{2}{*}{0.505} \\
\hline & 2 & 49 & 1.49 & 1.063 & \\
\hline \multirow{2}{*}{ Anxiety (inner restlessness, feeling panicky) } & 1 & 36 & 0.92 & 1.131 & \multirow{2}{*}{0.357} \\
\hline & 2 & 49 & 1.14 & 1.099 & \\
\hline \multirow{2}{*}{$\begin{array}{l}\text { Physical and mental } \\
\text { exhaustion (general decrease } \\
\text { in performance, impaired memory, decrease in } \\
\text { concentration, forgetfulness) }\end{array}$} & 1 & 36 & 1.58 & 0.937 & \multirow{2}{*}{0.390} \\
\hline & 2 & 49 & 1.78 & 1.066 & \\
\hline \multirow{2}{*}{$\begin{array}{l}\text { Sexual problems (change in sexual desire, in } \\
\text { sexual activity and satisfaction) }\end{array}$} & 1 & 35 & 0.91 & 0.951 & \multirow{2}{*}{0.015} \\
\hline & 2 & 48 & 1.48 & 1.072 & \\
\hline \multirow{2}{*}{$\begin{array}{l}\text { Bladder problems (difficulty in urinating, } \\
\text { increased need to urinate, bladder incontinence) }\end{array}$} & 1 & 36 & 0.75 & 0.841 & \multirow{2}{*}{0.283} \\
\hline & 2 & 49 & 0.98 & 1.051 & \\
\hline \multirow{2}{*}{$\begin{array}{l}\text { Dryness of vagina (sensation of dryness or burning } \\
\text { in the vagina, difficulty with sexual intercourse) }\end{array}$} & 1 & 36 & 0.64 & 0.833 & \multirow{2}{*}{0.010} \\
\hline & 2 & 48 & 1.19 & 1.024 & \\
\hline \multirow{2}{*}{$\begin{array}{l}\text { Joint and muscular discomfort (pain in the joints, } \\
\text { rheumatoid complaints) }\end{array}$} & 1 & 36 & 0.97 & 0.971 & \multirow{2}{*}{0.018} \\
\hline & 2 & 48 & 1.52 & 1.072 & \\
\hline
\end{tabular}

Legend/Legenda: Group 1/Skupina 1 - women in perimenopause/ženske vperimenopavzi; Group 2/Skupina 2 - women in menopause/ ženske v menopavzi; $n$ - number/število; $s$ - standard deviation/standardni odklon; $\bar{x}$ - average value/povprečna vrednost; $p$ statistical significance/statistična značilnost 
Other symptoms were only moderate $(M=2)$. Least commonly reported symptoms included bladder problems (difficulty in urinating, increased need to urinate, urinary incontinence) and dryness of vagina (sensation of dryness or burning in the vagina, difficulty with sexual intercourse).

Table 1 presents statistically significant differences in the participants' perceived level of severity of perimenopausal and menopausal symptoms. The study results show that women in menopause experience statistically significantly more sexual problems $(p$ $=0.015)$ than women in postmenopause. These symptoms include waned sexual desire or interest, decreased sexual activity and satisfaction. Women in menopause also statistically significantly more frequently report dryness of vagina $(p=0.010)$ and joint and muscular discomfort $(p=0.018)$.

The correlation was calculated between the values obtained for the symptoms experienced by women in perimenopause and the women in menopause. Highlighted are the most important findings, i.e. those with correlation coefficient of more than 0.5. As a result of mood swings, the interviewees often feel misunderstood and find it difficult to talk about their problems $(r=0.508, p<0.001)$. They feel that their self-image has changed $(r=0.577, p<0.001)$. The age-related changes (dry skin, sagging breasts) have a negative impact on their self-esteem and feelings of self-worth $(r=0.680, p<0.001)$. The interviewees also admit that they do not have enough knowledge to address the menopausal symptoms $(r=0.534, p<$ $0.001)$. They report that their world has been turned upside down, they feel less feminine with the end of their fertile period $(r=0.532, p<0.001)$, and that they have not been properly prepared for menopause $(r$ $=0.558, p<0.001)$. The women who described their sensations of heart discomfort (suddenly I become aware of my heart beat, heart skipping and heart racing), also experienced mood disorders (I am feeling down, sad, on the verge of tears, I feel a lack of motivation and drive, I suffer from mood swings) ( $r=$ $0.549, p<0.001)$. These feelings are often accompanied by irritability (I feel nervous, tense and aggressive) $(r$ $=0.843, p<0.001$ ) and anxiety (inner restlessness, feeling panicky) $(r=0.747, p<0.001)$. Physical and mental exhaustion (general decrease in performance, impaired memory, decrease in concentration, forgetfulness) is statistically correlated with mood disorders $(r=0.647, p<0.001)$.

As shown in Table 2, the interviewees most frequently, however occasionally, sought information about menopause in the printed media (newspapers, magazines) $(M=2)$, on the internet (generally) $(M=$ $2)$, and from their gynaecologist $(M=2)$. They hardly ever discussed menopause and menopause-related symptoms with their general physician $(M=4)$ and never with a nurse in an out-patient clinic.

The open-ended question was included in order to give the respondents an opportunity to express their subjective opinions and views on the perimenopause and menopause transition periods. The question was answered by $63(61.9 \%)$ respondents. Nine coding categories were derived from the text data, on the basis of which four subcategories were designed (positive attitude and self-

Table 2: Searching for information related to health and menopause

Tabela 2: Iskanje informacij $v$ zvezi $z$ zdravjem in menopavzo

\begin{tabular}{|c|c|c|c|c|c|c|c|c|c|}
\hline $\begin{array}{l}\text { Sources of information } \\
\text { about perimenopause, } \\
\text { postmenopause and } \\
\text { health/ } \\
\text { Vir informacij o } \\
\text { perimenopavzi in } \\
\text { pomenopavzi ter } \\
\text { zdravju }\end{array}$ & $\begin{array}{l}\text { Often/ } \\
\text { Pogosto } \\
n \\
(\%)\end{array}$ & $\begin{array}{l}\text { Occasio- } \\
\text { nally/ } \\
\text { Občasno } \\
n \\
(\%)\end{array}$ & $\begin{array}{l}\text { Rarely/ } \\
\text { Redko } \\
n \\
(\%)\end{array}$ & $\begin{array}{l}\text { Almost } \\
\text { never/ } \\
\text { Skoraj } \\
\text { nikoli } \\
n \\
(\%)\end{array}$ & $\begin{array}{l}\text { Never/ } \\
\text { Nikoli } \\
n \\
(\%)\end{array}$ & $n$ & $\bar{x}$ & $s$ & $M$ \\
\hline $\begin{array}{l}\text { Newspapers and } \\
\text { magazines }\end{array}$ & $\begin{array}{l}16 \\
(17.4)\end{array}$ & $\begin{array}{l}33 \\
(35.9)\end{array}$ & $\begin{array}{l}15 \\
(16.3)\end{array}$ & $\begin{array}{l}12 \\
(13)\end{array}$ & $\begin{array}{l}16 \\
(17.4)\end{array}$ & 92 & 2.77 & 1.36 & 2 \\
\hline $\begin{array}{l}\text { Health manuals/books } \\
\text { on menopause }\end{array}$ & $\begin{array}{l}11 \\
(12) \\
\end{array}$ & $\begin{array}{l}33 \\
(36) \\
\end{array}$ & $\begin{array}{l}19 \\
(21) \\
\end{array}$ & $\begin{array}{ll}6 \\
(6) \\
\end{array}$ & $\begin{array}{l}23 \\
(25) \\
\end{array}$ & 92 & 2.97 & 1.39 & 3 \\
\hline Internet (generally) & $\begin{array}{l}20 \\
(21.5)\end{array}$ & $\begin{array}{l}31 \\
(33.3)\end{array}$ & $\begin{array}{l}16 \\
(17)\end{array}$ & $\begin{array}{l}9 \\
(10)\end{array}$ & $\begin{array}{l}17 \\
(18)\end{array}$ & 93 & 2.70 & 1.39 & 2 \\
\hline $\begin{array}{l}\text { Forums and chat rooms } \\
\text { on the internet }\end{array}$ & $\begin{array}{l}3 \\
(3.4) \\
\end{array}$ & $\begin{array}{l}12 \\
(13.8)\end{array}$ & $\begin{array}{l}4 \\
(4.6)\end{array}$ & $\begin{array}{l}17 \\
(19)\end{array}$ & $\begin{array}{l}51 \\
(59)\end{array}$ & 87 & 4.16 & 1.22 & 5 \\
\hline General practitioner & $\begin{array}{l}0 \\
(0)\end{array}$ & $\begin{array}{l}28 \\
(32)\end{array}$ & $\begin{array}{l}16 \\
(18)\end{array}$ & $\begin{array}{l}19 \\
(21)\end{array}$ & $\begin{array}{l}26 \\
(29)\end{array}$ & 89 & 3.48 & 1.21 & 4 \\
\hline Gynaecologist & $\begin{array}{l}7 \\
(7.4)\end{array}$ & $\begin{array}{l}43 \\
(45.3) \\
\end{array}$ & $\begin{array}{l}21 \\
(22)\end{array}$ & $\begin{array}{l}9 \\
(9.5) \\
\end{array}$ & $\begin{array}{l}15 \\
(16) \\
\end{array}$ & 95 & 2.81 & 1.20 & 2 \\
\hline Nurse & $\begin{array}{l}0 \\
(0)\end{array}$ & $\begin{array}{l}9 \\
(9.8) \\
\end{array}$ & $\begin{array}{l}13 \\
(14)\end{array}$ & $\begin{array}{l}17 \\
(18.5)\end{array}$ & $\begin{array}{l}53 \\
(57.6) \\
\end{array}$ & 92 & 4.24 & 1.03 & 5 \\
\hline
\end{tabular}

Legend/Legenda: $n$ - number/število; $s$-standard deviation/standardni odklon; $\bar{x}-$ average value/povprečna vrednost; $M-$ median/ mediana, \% - percentage/odstotek 
Table 3: Presentation of the codes and subcategories with some statements Tabela 3: Prikaz kod in podkategorij z izjavami

\begin{tabular}{|c|c|c|c|c|}
\hline $\begin{array}{l}\text { Statements/ } \\
\text { Izjave }\end{array}$ & $\begin{array}{l}\text { Codes/ } \\
\text { Kode }\end{array}$ & $\begin{array}{l}f \\
(\%)\end{array}$ & $\begin{array}{l}\text { Subcategories/ } \\
\text { Podkategorije }\end{array}$ & $\begin{array}{l}\text { Category/ } \\
\text { Kategorija }\end{array}$ \\
\hline $\begin{array}{l}\text { 'Transition is a new experience we should not fear, it is } \\
\text { important to be prepared and take it as a natural stage of } \\
\text { life.' } \\
\text { 'I experienced perimenopause and menopause as a } \\
\text { natural stage of life.' } \\
\text { 'I was informed and prepared to accept all the symptoms.' }\end{array}$ & $\begin{array}{l}\text { Menopause as } \\
\text { a natural stage } \\
\text { of life }\end{array}$ & $\begin{array}{l}32 \\
(33.4)\end{array}$ & \multirow[t]{3}{*}{$\begin{array}{l}\text { Positive } \\
\text { attitude } \\
\text { and self- } \\
\text { confidence }\end{array}$} & \multirow[t]{9}{*}{$\begin{array}{l}\text { Experiencing } \\
\text { the } \\
\text { premenopause } \\
\text { and } \\
\text { menopause }\end{array}$} \\
\hline 'The time has come to put myself in the first place.' & Self-care & $\begin{array}{l}6 \\
(5.4)\end{array}$ & & \\
\hline $\begin{array}{l}\text { 'I am terrified of aging.' } \\
\text { 'I was afraid to have fallen seriously ill.' }\end{array}$ & $\begin{array}{l}\text { Insecurity, } \\
\text { fear, stress }\end{array}$ & $\begin{array}{l}7 \\
(7.2)\end{array}$ & & \\
\hline $\begin{array}{l}\text { 'I begin to recognise the importance of regular physical } \\
\text { activity.' }\end{array}$ & $\begin{array}{l}\text { Physical } \\
\text { activity }\end{array}$ & $\begin{array}{l}3 \\
(3.1)\end{array}$ & \multirow[t]{2}{*}{$\begin{array}{l}\text { Healthy } \\
\text { lifestyle }\end{array}$} & \\
\hline $\begin{array}{l}\text { 'I am aware that I could do much more for myself in terms } \\
\text { of regular and quality diet and nutrition.' } \\
\text { 'To overcome fear and anxiety you have to be physically } \\
\text { active and eat healthy.' }\end{array}$ & $\begin{array}{l}\text { Healthy and } \\
\text { balanced diet }\end{array}$ & $\begin{array}{l}6 \\
(6)\end{array}$ & & \\
\hline $\begin{array}{l}\text { 'In my opinion, many problems could be avoided } \\
\text { if information and counselling were provided by a } \\
\text { gynaecologist.' }\end{array}$ & Be informed & $\begin{array}{l}6 \\
(5.7)\end{array}$ & \multirow[t]{2}{*}{ Information } & \\
\hline $\begin{array}{l}\text { 'I knew very little about this life stage. Only when my } \\
\text { health problems became serious, the health workers } \\
\text { treated me accordingly.' }\end{array}$ & $\begin{array}{l}\text { Ignorance of } \\
\text { symptoms }\end{array}$ & $\begin{array}{l}2 \\
(2.9)\end{array}$ & & \\
\hline $\begin{array}{l}\text { 'It is important to talk about the issue in question with } \\
\text { people whom we trust.' } \\
\text { '.... it is important to discuss these things.' }\end{array}$ & Discussion & $\begin{array}{l}4 \\
(3.8)\end{array}$ & \multirow[t]{2}{*}{$\begin{array}{l}\text { Support of the } \\
\text { environment }\end{array}$} & \\
\hline $\begin{array}{l}\text { '... I have a friend. We discussed this issue a lot and she } \\
\text { was the one who helped me most in coping with this } \\
\text { transition.' } \\
\text { 'A good partner relationship was of crucial importance...' }\end{array}$ & Support & $\begin{array}{l}3 \\
(1.7)\end{array}$ & & \\
\hline
\end{tabular}

confidence; healthy lifestyle, awareness/information and support), which are shown in Table 3. The latter includes the codes, further separated into subcategories and a category, with some statements or phrases, their codes and the frequency of statements linked into individual codes. The participants most frequently stated that the period of perimenopause and menopause should be accepted as a natural stage of life (33.4\%), $7.2 \%$ claimed that this period is replete with worries, fears and insecurity, $5.4 \%$ emphasised the importance of positive approach to menopause and self-care, $6 \%$ stressed the importance of a healthy diet, $5.7 \%$ expressed the need for more information on this gradual life transition, $2.9 \%$ were not aware of menopausal symptoms, $3.8 \%$ assigned special importance to discussing the problems, $1.7 \%$ to the support of their family and friends, and 3.1 $\%$ underlined the importance of physical activity during this period.

\section{Discussion}

The study addresses the menopause, with its positive sides, and a series of symptoms due to physiologic hormonal changes in this transitional period in women's life. Menopause is a natural and universal event of the human female life cycle. However, it is a period that is different for each individual, depending on their attitude towards themselves, menopause and health. Kopčavar Guček and Franić (2008) stated that nowadays, most women spend more than one-third of their lives in menopause due to longer overall survival and greater life expectancy. Women, on average, live longer than men and they will therefore enjoy fewer years of healthy life as they will experience longer periods of poor health (Vertot, 2010). The majority of interviewees rate their current health as good, with no identified chronic diseases. The study findings indicate that women are aware of what they should do or avoid in terms of lifestyle and diet to improve their health condition. Most of them regularly attend preventive examinations/screening tests and one third of them engage in regular physical activity even more than three times per week. It was established that only one third of the participants attend to their body weight and follow a healthy, balanced diet.

Sveinsdóttir and Ólafsson (2006) found that Islandic women generally have a positive attitude towards menopause and consider it a natural transition which can not be prevented. The results of the present study indicate that the participants were most commonly 
saddened by the signs of aging, they felt tired and exhausted due to sleep problems. They had negative attitudes to hormone replacement therapy being aware of their possible side effects, but expressed satisfaction that they no longer needed to fear unwanted pregnancy. Some other authors (Črnigoj \& Prosen, 2016) also claim that spontaneous sexual activity influences the quality of life and the relationship of a couple. Women in menopause may suffer from mood swings, one of the most common symptoms of menopause caused by hormonal fluctuations. The inappropriate or disproportionate emotional reaction to its cause or trigger is often misunderstood and therefore the study participants expressed their reluctance to discuss this issue. The study also raised the issue of women's changed self-image and adversely affected confidence due to the signs of aging (dry skin, sagging breasts). The respondents $(25 \%)$ reported they did not know enough about appropriate health and lifestyle interventions to alleviate their menopausal problems.

The participants reported that their world was turned upside down and they were not adequately prepared for this natural process of development. The evidence presented shows that the interviewed women have a need to discuss their menopausal complaints and that they need more health education and psychological support. One fourth of the respondents admitted that they do not know enough about menopause symptom management. The results of the present study related to the HRT, alternative therapies and sexual health are in line with the findings obtained by Cumming and collegues (2007), which indicate that the patients are let down with poor provision of information, inaccurate or wrong information, or access to the right care. It seems appropriate to provide information about women's health at all levels of health care, especially at a primary level, which is most widely accessible. The study research reveals that the respondents most frequently sought menopause-related information in newspapers and magazines, on the internet and from their gynaecologist. It is interesting to note that more than half of the respondents never turned to nurses in an out-patient clinic for information or advice. An action needs to be taken in order to strengthen the advisory role of nurses who are autonomous health professionals with competences to provide also health counselling, health promotion and health education (Železnik, et al., 2008). The study conducted by Pepić (2012) reveals that only $4.5 \%$ of the participants received health education related to menopause and climacterium from their gynaecologist and only 2.6 $\%$ from nurses. Similar results were obtained in the study conducted among Islandic menopause women (Sveinsdóttir \& Ólafsson, 2006). The participants of the present study confirmed that the information obtained (from other sources) was helpful. One of the reasons why women do not seek information in health institutions could be their denial of menopausal symptoms or because they want them keep hidden (Sergeant, 2015).

It was established that the respondents' most frequently cited symptoms include hot flushes, sweating, sleep disorders, and physical and mental exhaustion. Among the less frequent symptoms were heart discomfort, depressive mood with mood swings, irritability, and joint and muscular discomfort. The present study produced results which corroborate the findings of previous research (Sveinsdóttir \& Ólafsson, 2006; Chedraui, et al., 2007), where the same research instrument (MRS) was used. The studies conducted in Equador (Chedraui, et al., 2007) and Iceland (Sveinsdóttir \& Ólafsson, 2006) reveal that the most frequent symptoms reported by the studied population were pains in the muscles and joints, mood swings, sexual problems, hot flushes and sleep disorders.

Brown and collegues (2015) investigated the psychological distress during the menopause transition and also evaluated evidence on the relationship between menopausal factors (stage and symptoms) and indices of positive well-being. They concluded that little is known about the experience of positive well-being at this time and that positive well-being may be available for use as a resilience factor that women can draw on to meet the challenges that midlife presents. One third of the participants of the present study also highlighted the importance of a positive attitude towards this period, the changes, challenges and insecurity occurring during menopause, which indicates a positive attitude towards health and coping with menopausal symptoms.

More than half of the participants agreed that physical activity attenuates many of the adverse health effects that frequently accompany the menopausal transition. It may help prevent several chronic diseases. More than half of the participants engage in regular physical activity at least once or twice a week and one third of the participants exercise three times or more per week. Surprisingly, two thirds of the EU's population are not enough physically active despite the well-documented benefits of regular physical activity (Drev, 2010). According to the Spanish research (Villaverde-Gutierrez, et al., 2006), habitual participation in physical activity results in many health benefits and statistically significantly improves menopausal symptoms and the health-related quality of life in the postmenopausal period. Similar results were obtained in the literature review study conducted by Marn Radoš and Šćepanović (2014).

The assessment of the respondents' lifestyle included also factors over which patients have some control, including bad habits. One third of the respondents are smokers, which corresponds to the average smoking rate in the EU member states (Koprivnikar, 2010). The extensive research conducted in Denmark (Pisinger, et al., 2009) confirms the relationship between 
healthy lifestyle and self-reported health in a general population.

There were several requests for more information on menopause despite high educational level of the participants. This finding has an important implication for nurses in the referential family outpatient clinics who could provide also counselling to menopause women. Foreign research (Sveinsdóttir \& Ólafsson, 2006) established that action needs to be taken in order to strengthen the advisory role of nurses. The internationally well accepted standardised questionnaire MRS is recommended to measure the severity of menopausal symptoms in the referential family out-patient clinic, which proved useful also in the present study.

A limitation of the study was a relatively small sample size. For this reason, these results need to be interpreted with caution as they might not be transferable or generalized to a broader community. Further, more extensive targeted research on menopause and access to information needs therefore be undertaken on a larger sample of population. The present sample includes women with high average educational level, which should be taken into consideration in sampling of future research and comparison of results.

Further quantitative and qualitative studies with interviews are recommended to gain a better understanding and insight into the research problem. This recommendation is based also on the fact that a number of participants expressed a wish for further discussion of the issue.

\section{Conclusion}

There are some important issues emerging from this study. Most of the respondents rate their health as good or very good, they have a positive attitude towards health and live a healthy lifestyle. They are also aware of what they should do or avoid in terms of lifestyle and diet to improve their quality of life. They did, however, express the need for more information, especially from healthcare providers. At the end of the survey, a number of participants visited or called the interviewers and expressed a need for additional information on menopause which could be provided through lectures or workshops. It is important that health professionals offer women the information about all the symptoms, complications and some ways of controlling menopausal symptoms. Preparedness, positive attitude and knowledge help women embrace the physical, psychological and emotional changes occurring in menopause. Therefore, the authors suggest that the nurse in the family out-patient clinic introduces individual counselling on menopause or organises lectures or workshops for the targeted population of women aged 45-55 years. They also recommend the use of MRS questionnaire to measure the severity of symptoms. Additional education for nurses should be accordingly provided to empower nurses with the relevant knowledge. Additional tasks will require also additional workforce.

\section{Slovenian translation/Prevod $v$ slovenščino}

\section{Uvod}

Zdravje je ena temeljnih prvin našega življenja, saj zadovoljuje potrebo po preživetju in kakovostnem življenju (Štern, 2007). V zadnjih desetletjih se mnogi strokovnjaki ukvarjajo s težavami, ki se pojavljajo pri ženskah v perimenopavzi in pomenopavzi ter vplivajo na njihovo zdravje (Meden-Vrtovec, 2007). MedenVrtovec (2007) se ob tem sprašuje, kako bomo takšno žensko obravnavali - ali se bomo odločili spoznati, kakšne spremembe doživlja na telesnem in psihičnem področju ter kakšno pomoč ji lahko ponudimo. Spremembe v organizmu se dogajajo na več področjih in se odražajo tudi $\mathrm{v}$ psihičnem doživljanju, zato je koristno upoštevati vse vidike, ki se med seboj dopolnjujejo, in žensko obravnavati celostno (Mlakar, 2007). Obdobje, ki označuje leta pred in po menopavzi imenujemo klimakterij. Pojav in trajanje klimakterija Meden-Vrtovec (2002) opredeljuje kot obdobje štirih faz: predmenopavza $\mathrm{s}$ psihičnimi in somatskimi spremembami lahko tudi več let pred menopavzo; perimenopavza; menopavza, ki je trajno prenehanje menstruacije, in pomenopavza. V nadaljevanju članka te štiri faze obravnavamo združene $v$ dve obdobji: $\mathrm{z}$ izrazom perimenopavza poenostavljeno označujemo perimenopavzo in predmenopavzo, z izrazom menopavza pa obdobje menopavze in pomenopavze.

Menopavza je v življenju ženske obdobje, ko se mora spopasti $z$ vrsto izgub: zmanjšana reproduktivna sposobnost, izgubljen mladostni videz in spremembe v želji po spolnosti, spolni aktivnosti in zadovoljstvu $\mathrm{v}$ spolnosti. Prav tako se ženska v tem obdobju začne zavedati lastne minljivosti, kajti menopavzo vidi kot opomnik za spreminjanje, staranje ali umiranje (Vigeta, et al., 2012). Menopavzalne težave, ki jih ženske občutijo, zmanjšujejo kakovost njihovega življenja (Borko \& Žegura, 2006, p. 113), pri tem sta aktivni življenjski slog in redno gibanje pomembna varovalna dejavnika zdravja (Lainščak, et al., 2005; Labrinoudaki, et al., 2013). Marn Radoš in Šćepanović (2014) izpostavljata pomen zdravstvenovzgojnega svetovanja zdravstvenih delavcev o primernih oblikah telesne dejavnosti (npr. hitra hoja, hoja po stopnicah, tek ipd.), ki lahko doseže celotno ciljno populacijo ne glede na socialni status. Pomembno je, da zdravstveni delavci ženski razložijo, kaj se z njenim telesom dogaja, in ji ponudijo možnosti, s katerimi si lahko težave olajša, ter ji hkrati svetujejo o zdravem načinu življenja, ki vključuje primerno prehrano in dovolj gibanja (Petkovič, 2007). McCloskey (2012) v svoji raziskavi ugotavlja, da zdravstveni delavci 
procesa prehoda žensk v perimenopavzo še vedno ne poznajo dovolj dobro. Cumming in sodelavci (2015) tudi ugotavljajo, da zdravstveni delavci še naprej dopuščajo, da ženskam v menopavzi niso dostopne vse informacije, da dobijo netočne ali napačne podatke ali da nimajo dostopa do ustrezne zdravstvene oskrbe. Ceno za to plačujejo ženske, ki živijo s posledicami, povezanimi z menopavzo, ki bi se jih dalo preprečiti in ki posledično negativno vplivajo na zdravje in zdravstveno ekonomijo. Kot poudarja Mander (2012), je pomembno ženskam predstaviti možnosti, kako izboljšati kakovost življenja. Franić (2008) predlaga več aktivnosti na primarnem nivoju zdravstvenega varstva predvsem pri mlajših ženskah in njihovo ozaveščanje o možnostih zmanjševanja težav $\mathrm{v}$ kasnejših letih. Britansko združenje za menopavzo (BMSC) (British Menopause Society Council, 2011) priporoča, da bi bilo poleg sprememb na nivoju javne zdravstvene politike v timih primarnega zdravstva treba uvesti še register žensk, starejših od 45 let, in jih povabiti na posvetovanje o zdravju in zdravem načinu življenja.

\section{Namen in cilji}

Namen raziskave je bil raziskati stališča in odnos žensk do perimenopavzalnega in menopavzalnega obdobja, do zdravja in do zdravega življenjskega sloga ter nekatere vidike informiranosti v zvezi s tem obdobjem življenja. Postavljena so bila naslednja raziskovalna vprašanja:

- Kako ženske $\mathrm{v}$ perimenopavzi in menopavzi ocenjujejo svoje splošno zdravje?

- Kako ženske samoocenjujejo menopavzalne simptome glede na težavnost?

- Kje ženske pridobijo največ informacij v zvezi $\mathrm{z}$ menopavzo in zdravjem?

\section{Metode}

Uporabljeno je bilo neeksperimentalno opisno raziskovanje.

\section{Opis instrumenta}

$\mathrm{V}$ raziskavi je bil kot merski instrument uporabljen delno strukturirani vprašalnik, ki smo ga sestavili na podlagi pregleda strokovne literature (Borko \& Žegura, 2006; Meden-Vrtovec, 2007; Mlakar, 2007), deloma pa je bil povzet po Menopause Rating Scale (MRS), validiranem vprašalniku, ki je bil razvit $\mathrm{v}$ Nemčiji in je namenjen oceni težav žensk v menopavzi (Heinemann, et al., 2004). Vprašalnik je preveden v 25 jezikov, vendar ga v slovenščini ni, zato smo ga prevedli iz angleškega jezika. Vprašalnik je bil pilotno testiran na sedmih anketirankah in dopolnjen v štirih trditvah. Vprašalnik je vseboval 43 zaprtih in 2 odprti vprašanji, 16 vprašanj izbirnega tipa in 27 trditev, pri katerih smo pri 11 vprašanjih uporabili ocenjevalno lestvico simptomov po vprašalniku MRS (0 - nič, 1 - blagi, 2 - zmerni, 3 - težki, 4 - zelo težki). Pri 16 vprašanjih smo uporabi Likertovo petstopenjsko lestvico stališč, pri čemer je pomenilo 1 - popolnoma se ne strinjam, 2 - se ne strinjam, 3 - delno se strinjam, 4 - se strinjam, 5 - popolnoma se strinjam. Prvi del je bil namenjen demografskim podatkom ( 9 vprašanj), osrednji del pa se je nanašal na subjektivna stališča žensk v odnosu do težav, ki jih doživljajo v obdobju menopavze, na samooceno življenjskega sloga in razvad, na odnos do zdravja in na dostopnost informacij, povezanih $\mathrm{z}$ menopavzo. Zanesljivost vprašalnika je bila preverjena na podlagi koeficienta Cronbach alfa. Skupna vrednost koeficienta Cronbach alfa je bila 0,813, kar kaže na dobro zanesljivost instrumenta (Cencič, 2009).

\section{Opis vzorca}

Izbrali smo slučajnostni sistematični vzorec. Vanj smo vključili ženske, ki so imele opredeljenega izbranega osebnega zdravnika $\mathrm{v}$ zasebni zdravstveni ustanovi s koncesijo, katere osnovna dejavnost je zdravstveno varstvo odraslih, ki obsega preventivno varstvo, odkrivanje, zdravljenje in obravnavo bolezni ali poškodb. Vzorec anketirank je bil omejen s starostjo med 45 in 60 let. S pomočjo računalniškega programa DDM 3,0 smo iz abecednega seznama vseh žensk predvidene vključitvene starosti izbrali vsako peto žensko, kar pomeni razmerje 1:4. Vzorec je vključeval 120 anketirank in predstavlja $20 \%$ populacije oz. opredeljenih žensk v tej ustanovi v starosti 45 do 60 let. V raziskavi je sodelovalo 100 žensk, kar predstavlja 83\% odzivnost. Največja starostna skupina je bila 50-54 let (41,7\%), vključevala je 41 vprašanih; 24 vprašanih $(25,7 \%)$ je bilo starih 45-49 let, nad 55 let pa je bilo 35 (32,5 \%) vprašanih. Analiza formalne izobrazbene strukture je pokazala, da je največ, in sicer 38 anketirank (38,7 \%) imelo visokošolsko univerzitetno izobrazbo; najmanj, le 3 (1,2 $\%)$ anketiranke so kot formalno izobrazbo navedle samo dokončano ali nedokončano osnovno šolo. Zaposlitveni status žensk, ki so sodelovale v raziskavi, je bil sledeč: 83 $(81,8 \%)$ zaposlenih, 7 (10,1 \%) nezaposlenih in le $9(7 \%)$ upokojenih; ena anketiranka na vprašanje ni odgovorila. $\mathrm{Na}$ vprašanje o finančnem statusu se je $65(63,1 \%)$ vprašanih opredelilo, da zaslužijo ravno dovolj, $9(10,4$ \%) jih meni, da zaslužijo celo več, kot potrebujejo, 25 (25,8 \%) vprašanih pa s svojim zaslužkom ni zadovoljnih; ena anketiranka ni podala odgovora.

Glede na delitev obdobja po Meden-Vrtovec (2002) je bilo 37 (40,1\%) anketirank v predmenopavzi oziroma perimenopavzi in 49 (44,5\%) anketirank v menopavzi oziroma v pomenopavzi; 14 anketirank ni podalo odgovora.

\section{Opis poteka raziskave in obdelave podatkov}

Raziskava je potekala na primarni ravni zdravstvenega varstva, in sicer v osnovni zdravstveni dejavnosti, $\mathrm{v}$ ambulanti družinske medicine. Izbranim ženskam 
zasebne zdravstvene ustanove smo na dom poslali vprašalnik $s$ prošnjo za sodelovanje in s pojasnitvijo namena raziskave ter s priloženo frankirano kuverto. Raziskava je bila prostovoljna in anonimna ter $\mathrm{v}$ skladu $\mathrm{z}$ etičnimi načeli raziskovanja. Vzorčenje je potekalo oktobra 2014.Zvprašalnikom pridobljene podatke smo obdelali s programoma Microsoft Excel in SPSS verzija 20.0 (SPSS Inc., Chicago, IL). Socialnodemografske podatke smo obdelali $\mathrm{z}$ deskriptivno statistiko. Za statistične spremenljivke smo izračunali frekvence, odstotke, mere srednje vrednosti (aritmetično sredino) in razpršenosti (standardni odklon). Statistično pomembne razlike med skupino žensk, ki so $\mathrm{v}$ perimenopavzi, in skupino žensk, ki so že v menopavzi, smo ugotavljali $\mathrm{s}$ t-testom, za oceno korelacijskih povezav pa smo uporabili Pearsonov korelacijski koeficient. Statistično pomembnost je predstavljala vrednost $p<0,05$.

Vsebinski odgovor na odprto vprašanje je podala več kot polovica sodelujočih. Besedilo smo analizirali $s$ kvalitativnim raziskovalnim pristopom glede na že postavljeno kategorijo doživljanje obdobja menopavze $\mathrm{s}$ tehniko seštevalne analize besedila (Hsieh \& Shannon, 2005). Iz podanih vsebinskih odgovorov smo besednim zvezam določili kode, ki smo jih nato glede na soroden pomen združili, in prepoznanim kodam določili še podkategorije.

\section{Rezultati}

$\mathrm{V}$ raziskavi ugotavljamo, da je svoje trenutno splošno zdravstveno stanje $58 \%$ anketiranih ocenilo kot dobro, $12 \%$ jih je menilo, da je njihovo zdravje zelo dobro, $22 \%$ jih je bilo s svojim zdravjem srednje zadovoljnih, $3 \%$ anketiranke so svoje zdravje označile kot slabo, $2 \%$ vprašani pa sta menili, da je njuno trenutno splošno zdravje zelo slabo; 3 anketiranke svojega mnenja niso podale. Nanašajoč se na vprašanje o splošnem zdravstvenem stanju smo anketiranke povprašali o morebitnih kroničnih nenalezljivih boleznih, kot so arterijska hipertenzija, sladkorna bolezen, astma ipd.: 69 (70,4\%) anketiranih ni imelo nobene od kroničnih nenalezljivih bolezni, $1(1,9 \%)$ ni vedela, da bi imela kronično nenalezljivo bolezen, 29 (26,4 \%) anketiranih pa je imelo vsaj eno od teh bolezni.

Želeli smo ugotoviti, kakšen odnos imajo anketiranke do zdravega načina življenja. Analiza podatkov za več možnih odgovorov je pokazala, da je $12(12,1 \%)$ anketiranih močno strah za njihovo zdravje, $86(86,9$ $\%)$ jih je menilo, da za svoje zdravje lahko veliko storijo same, $51(51,5 \%)$ jih redno hodi na preventivne/ presejalne preglede, $30(30,3 \%)$ jih je odgovorilo, da se zelo trudijo vzdrževati ustrezno telesno težo, 41 $(41,4 \%)$ jih je navedlo, da so redno telesno aktivne in da skrbijo za ustrezno telesno kondicijo, $30(30,3$ $\%)$ jih skrbi za redno in ustrezno prehrano, $35(35,4$ $\%)$ pa jih je menilo, da se premalo gibajo, $13(13,1$ $\%)$, da je njihova prehrana neredna in neustrezna,
3 (3\%) anketiranke pa so odgovorile, da na svoje zdravje sploh ne pazijo.

Zanimalo nas je tudi subjektivno stališče doživljanja težav v perimenopavzi. Uporabljena je bila Likertova petstopenjska lestvica stališč. Glede na ugotovljeno srednjo vrednost - mediano (M) so se anketiranke delno strinjale $(M=3) \mathrm{z}$ dejstvom, da so jih žalostili znaki staranja, ki so jih opažale, mučila jih je utrujenost in izčrpanost zaradi nespečnosti in zaradi mogočih neželenih učinkov jih je bilo strah jemati hormonsko nadomestno zdravljenje (HNZ). Delno so se tudi strinjale $(M=3) \mathrm{z}$ zadovoljstvom ob dejstvu, da jim ni treba več skrbeti zaradi neželene nosečnosti. Večinoma se anketiranke popolnoma niso strinjale $\mathrm{z}$ dejstvom $(M=1)$, da bi se počutile manj žensko, ker niso več v rodni dobi. Rezultati drugih trditev kažejo, da se $\mathrm{z}$ večino trditev anketiranke niso strinjale $(M$ $=2)$. Trinajst $(13,7 \%)$ anketirank je bilo zadovoljnih ali zelo zadovoljnih, da si lahko pri premagovanju menopavzalnih težav pomagajo s HNZ, 46 (48,9 \%) se jih je strinjalo ali zelo strinjalo s trditvijo, da jih je strah jemanja HNZ zaradi možnih neželenih učinkov, in 25 (26\%) jih je menilo, da o možnostih lajšanja menopavzalnih težav sploh premalo vedo.

$\mathrm{V}$ raziskavi smo uporabili mednarodno lestvico za ugotavljanje menopavzalnih težav MRS, kjer je bilo treba s petstopenjsko vrednostno lestvico oceniti težavnostno stopnjo simptomov (od 0 - nič, do 4 - zelo težki). Izračunane srednje vrednosti, ki opredeljujejo pojav težkih simptomov $(M=3)$ kažejo, da so imele ženske največ težav $\mathrm{z}$ vročinskimi oblivi in navali znojenja, s spanjem (težko uspavanje, prebujanje ponoči in prezgodnje prebujanje) in $s$ fizično ter psihično izčrpanostjo (splošna manjša učinkovitost, manjša zbranost in večja pozabljivost). Ostali simptomi so bili glede na srednjo vrednost $(M=2)$ zmerni. Najmanj težav so anketiranke imele s sečnim mehurjem (težave pri uriniranju, pogosto uriniranje, uhajanje urina - urinska inkontinenca) in suho nožnico (občutek suhosti ali žarenja v nožnici, težave pri spolnem odnosu).

Tabela 1 prikazuje statistično značilne razlike glede na oceno doživljanja stopnje težavnosti menopavzalnih simptomov $\mathrm{v}$ perimenopavzalnem obdobju in menopavzi. Rezultati so pokazali, da imajo ženske $\mathrm{v}$ menopavzi statistično pomembno $(p=$ $0,015)$ več spolnih težav, ki se kažejo kot spremembe v želji po spolnosti, spolni aktivnosti in zadovoljstvu v spolnosti. V skupini žensk, ki so v menopavzi, je statistično pomembno več tudi težav s suho nožnico $(p=0,010)$ ter težav $\mathrm{z}$ bolečinami v mišicah in sklepih $(p=0,018)$.

Izračunali smo korelacijo med trditvami v razdelku, kjer se anketiranke opredelijo o simptomih $\mathrm{v}$ perimenopavzi, in v razdelku, kjer opišejo simptome, ki jih doživljajo $\mathrm{v}$ menopavzi. Izpostavljamo najpomembnejše ugotovitve oz. tiste, kjer je bil korelacijski faktor več kot 0,5. Anketiranke, ki 
Tabela 1: Primerjava skupine žensk $v$ perimenopavzi s skupino žensk v menopavzi glede na jakost menopavzalnih simptomov

Table 1: Comparison of groups of women in perimenopause and menopause regarding the severity of menopause symptoms

\begin{tabular}{|c|c|c|c|c|c|}
\hline $\begin{array}{l}\text { Simptomi/ } \\
\text { Symptoms }\end{array}$ & $\begin{array}{l}\text { Skupina/ } \\
\text { Group }\end{array}$ & $n$ & $\bar{x}$ & $s$ & $p$ \\
\hline \multirow{2}{*}{ Vročinski oblivi, znojenje (navali znojenja) } & 1 & 36 & 1,11 & 0,919 & \multirow{2}{*}{0,111} \\
\hline & 2 & 49 & 1,49 & 1,175 & \\
\hline \multirow{2}{*}{$\begin{array}{l}\text { Težave s srcem (nenadno razbijanje srca, srce preskakuje, } \\
\text { pospešen utrip) }\end{array}$} & 1 & 36 & 0,92 & 0,937 & \multirow{2}{*}{0,418} \\
\hline & 2 & 49 & 1,10 & 1,104 & \\
\hline \multirow{2}{*}{$\begin{array}{l}\text { Težave s spanjem (težko zaspim, ponoči se prebujam, zjutraj se } \\
\text { prezgodaj prebujam) }\end{array}$} & 1 & 36 & 1,61 & 1,076 & \multirow{2}{*}{0,490} \\
\hline & 2 & 48 & 1,79 & 1,254 & \\
\hline \multirow{2}{*}{$\begin{array}{l}\text { Motnje razpoloženja (depresivna sem, žalostna, na robu solz, } \\
\text { nimam volje, razpoloženje niha) }\end{array}$} & 1 & 36 & 1,33 & 1,146 & \multirow{2}{*}{0,295} \\
\hline & 2 & 49 & 1,59 & 1,098 & \\
\hline \multirow{2}{*}{ Razdražljivost (počutim se nervozno, napeto, agresivno) } & 1 & 36 & 1,33 & 1,069 & \multirow{2}{*}{0,505} \\
\hline & 2 & 49 & 1,49 & 1,063 & \\
\hline \multirow{2}{*}{ Tesnoba (občutim nemir, loteva se me panika) } & 1 & 36 & 0,92 & 1,131 & \multirow{2}{*}{0,357} \\
\hline & 2 & 49 & 1,14 & 1,099 & \\
\hline \multirow{2}{*}{$\begin{array}{l}\text { Fizična in psihična izčrpanost (splošna manjša učinkovitost, } \\
\text { manjša zbranost in slabši spomin - večja pozabljivost) }\end{array}$} & 1 & 36 & 1,58 & 0,937 & \multirow{2}{*}{0,390} \\
\hline & 2 & 49 & 1,78 & 1,066 & \\
\hline \multirow{2}{*}{$\begin{array}{l}\text { Spolne težave (spremembe v želji po spolnosti, spolni } \\
\text { aktivnosti in zadovoljstvu) }\end{array}$} & 1 & 35 & 0,91 & 0,951 & \multirow{2}{*}{0,015} \\
\hline & 2 & 48 & 1,48 & 1,072 & \\
\hline \multirow{2}{*}{$\begin{array}{l}\text { Težave s sečnim mehurjem (težave pri uriniranju, pogosto } \\
\text { uriniranje, uhajanje urina - urinska inkontinenca) }\end{array}$} & 1 & 36 & 0,75 & 0,841 & \multirow{2}{*}{0,283} \\
\hline & 2 & 49 & 0,98 & 1,051 & \\
\hline \multirow{2}{*}{$\begin{array}{l}\text { Suha nožnica (občutek suhosti ali žarenja v nožnici, } \\
\text { težave pri spolnem odnosu) }\end{array}$} & 1 & 36 & 0,64 & 0,833 & \multirow{2}{*}{0,010} \\
\hline & 2 & 48 & 1,19 & 1,024 & \\
\hline \multirow{2}{*}{$\begin{array}{l}\text { Težave z mišicami in sklepi (bolečine v sklepih, revmatske } \\
\text { težave) }\end{array}$} & 1 & 36 & 0,97 & 0,971 & \multirow{2}{*}{0,018} \\
\hline & 2 & 48 & 1,52 & 1,072 & \\
\hline
\end{tabular}

Legenda/Legend: Skupina 1/Group 1 - ženske v perimenopavzi/women in perimenopause; Skupina 2/Group 2 - ženske v menopavzi/ women in menopause; $n$ - število/number; $s$ - standardni odklon/standard deviation; $\bar{x}-$ povprečna vrednost/average value; $p-$ statistična značilnost/statistical significance

zaradi pogostega nihanja njihovega razpoloženja čutijo nerazumevanje okolice, se o teh težavah težko pogovarjajo $(r=0,508, p<0,001)$ in čutijo, da je njihova samopodoba spremenjena $(r=0,577, p<$ 0,001 ). Pri tistih, ki opažajo znake staranja (suha koža, povešene prsi), kar jih dodatno žalosti, je tudi samopodoba spremenjena $(r=0,680, p<0,001)$, te anketiranke tudi menijo, da o možnostih lajšanja menopavzalnih težav premalo vedo $(r=0,534, p<$ $0,001)$. Anketiranke navajajo, da se jim je življenje postavilo na glavo, počutijo se manj žensko, ker niso več $\mathrm{v}$ rodni dobi $(r=0,532, p<0,001)$, in menijo, da na to obdobje niso bile dovolj pripravljene $(r=$ $0,558, p<0,001)$. Anketiranke, ki navajajo težave $s$ srcem (nenadoma občutim razbijanje srca, srce mi preskakuje, pospešeno utripa), navajajo tudi motnje razpoloženja (depresivna sem, žalostna, na robu solz, nimam volje, razpoloženje niha) $(r=0,549, p<0,001)$. Tiste anketiranke, ki navajajo zgoraj navedene motnje razpoloženja, navajajo tudi razdražljivost (počutim se nervozno, napeto, agresivno) $(r=0,843, p<0,001)$ in tesnobo (občutim nemir, loteva se me panika) $(r$ $=0,747, p<0,001)$. Fizična in psihična izčrpanost (splošna manjša učinkovitost, manjša zbranost in slabši spomin - večja pozabljivost) je statistično povezana ( $r$ $=0,647, p<0,001) \mathrm{z}$ motnjami razpoloženja.

Kot prikazuje Tabela 2 so anketiranke glede na srednjo vrednost (mediana) najpogosteje, vendar občasno informacije iskale $\mathrm{v}$ časopisih in revijah $(M=$ $2)$, na internetu (splošno) $(M=2)$ ter pri ginekologu $(M=2)$. Skoraj nikoli niso iskale informacij v zvezi z menopavzo in zdravjem pri splošnem zdravniku $(M=4)$ ter nikoli pri medicinski sestri $\mathrm{v}$ ambulanti $(M=5)$.

Z odprtim vprašanjem smo od anketirank želeli pridobiti tudi njihovo subjektivno mnenje o doživljanju prehoda v perimenopavzo in menopavzo. Na vprašanje je odgovorilo 63 (61,9 \%) anketirank. Prepoznali smo devet kod in iz njih oblikovali štiri podkategorije (pozitivna naravnanost in samozaupanje, zdrav 
Tabela 2: Iskanje informacij $v$ zvezi z zdravjem in menopavzo

Table 2: Searching for information related to health and menopause

\begin{tabular}{|c|c|c|c|c|c|c|c|c|c|}
\hline $\begin{array}{l}\text { Vir informacij o } \\
\text { perimenopavzi in } \\
\text { pomenopavzi ter } \\
\text { zdravju/ } \\
\text { Sources of information } \\
\text { about perimenopause, } \\
\text { postmenopause and } \\
\text { health }\end{array}$ & $\begin{array}{l}\text { Pogosto/ } \\
\text { Often } \\
n \\
(\%)\end{array}$ & $\begin{array}{l}\text { Občasno/ } \\
\text { Occasio- } \\
\text { nally } \\
n \\
(\%)\end{array}$ & $\begin{array}{l}\text { Redko/ } \\
\text { Rarely } \\
n \\
(\%)\end{array}$ & $\begin{array}{l}\text { Skoraj } \\
\text { nikoli/ } \\
\text { Almost } \\
\text { never } \\
n \\
(\%)\end{array}$ & $\begin{array}{l}\text { Nikoli/ } \\
\text { Never } \\
n \\
(\%)\end{array}$ & $n$ & $\bar{x}$ & $s$ & $M$ \\
\hline $\mathrm{V}$ časopisih in revijah & $\begin{array}{l}16 \\
(17,4)\end{array}$ & $\begin{array}{l}33 \\
(35,9)\end{array}$ & $\begin{array}{l}15 \\
(16,3)\end{array}$ & $\begin{array}{l}12 \\
(13)\end{array}$ & $\begin{array}{l}16 \\
(17,4)\end{array}$ & 92 & 2,77 & 1,36 & 2 \\
\hline $\begin{array}{l}\text { V zdravstvenih } \\
\text { priročnikih in/ali } \\
\text { knjigah o menopavzi }\end{array}$ & $\begin{array}{l}11 \\
(12)\end{array}$ & $\begin{array}{l}33 \\
(36)\end{array}$ & $\begin{array}{l}19 \\
(21)\end{array}$ & $\begin{array}{l}6 \\
(6)\end{array}$ & $\begin{array}{l}23 \\
(25)\end{array}$ & 92 & 2,97 & 1,39 & 3 \\
\hline Na internetu (splošno) & $\begin{array}{l}20 \\
(21,5)\end{array}$ & $\begin{array}{l}31 \\
(33,3)\end{array}$ & $\begin{array}{l}16 \\
(17)\end{array}$ & $\begin{array}{l}9 \\
(10)\end{array}$ & $\begin{array}{l}17 \\
(18)\end{array}$ & 93 & 2,70 & 1,39 & 2 \\
\hline $\begin{array}{l}\text { Na forumih ali } \\
\text { klepetalnicah na } \\
\text { internetu }\end{array}$ & $\begin{array}{l}3 \\
(3,4)\end{array}$ & $\begin{array}{l}12 \\
(13,8)\end{array}$ & $\begin{array}{l}4 \\
(4,6)\end{array}$ & $\begin{array}{l}17 \\
(19)\end{array}$ & $\begin{array}{l}51 \\
(59)\end{array}$ & 87 & 4,16 & 1,22 & 5 \\
\hline Pri splošnem zdravniku & $\begin{array}{l}0 \\
(0) \\
\end{array}$ & $\begin{array}{l}28 \\
(32) \\
\end{array}$ & $\begin{array}{l}16 \\
(18) \\
\end{array}$ & $\begin{array}{l}19 \\
(21)\end{array}$ & $\begin{array}{l}26 \\
(29) \\
\end{array}$ & 89 & 3,48 & 1,21 & 4 \\
\hline Pri ginekologu & $\begin{array}{l}7 \\
(7,4)\end{array}$ & $\begin{array}{l}43 \\
(45,3)\end{array}$ & $\begin{array}{l}21 \\
(22)\end{array}$ & $\begin{array}{l}9 \\
(9,5)\end{array}$ & $\begin{array}{l}15 \\
(16)\end{array}$ & 95 & 2,81 & 1,20 & 2 \\
\hline Pri medicinski sestri & $\begin{array}{l}0 \\
(0)\end{array}$ & $\begin{array}{l}9 \\
(9,8)\end{array}$ & $\begin{array}{l}13 \\
(14)\end{array}$ & $\begin{array}{l}17 \\
(18,5)\end{array}$ & $\begin{array}{l}53 \\
(57,6)\end{array}$ & 92 & 4,24 & 1,03 & 5 \\
\hline
\end{tabular}

Legenda/Legend: $n$-število/number; $s$ - standardni odklon/standard deviation; $\bar{x}$ - povprečna vrednost/average value; $M-m e d i a n a /$ median, \% - odstotek/percentage

Tabela 3: Prikaz kod in podkategorij z izjavami

Table 3: Presentation of the codes and subcategories with some statements

\begin{tabular}{|c|c|c|c|c|}
\hline $\begin{array}{l}\text { Izjave/ } \\
\text { Statements }\end{array}$ & $\begin{array}{l}\text { Kodel } \\
\text { Code }\end{array}$ & $\begin{array}{l}f \\
(\%)\end{array}$ & $\begin{array}{l}\text { Podkategorije/ } \\
\text { Subcategories }\end{array}$ & $\begin{array}{l}\text { Kategorija/ } \\
\text { Category }\end{array}$ \\
\hline $\begin{array}{l}\text { "Prehod je nova preizkušnja, ki se je ni treba bati, le } \\
\text { pripraviti se je treba nanj in ga sprejeti kot naraven proces } \\
\text { v življenjskem ciklusu." } \\
\text { "Obdobje perimenopavze in menopavze sem doživljala } \\
\text { kot naravno obdobje teh let." } \\
\text { "Vse znake sem pripravljena, osveščena sprejela." }\end{array}$ & $\begin{array}{l}\text { Vzeti kot del } \\
\text { življenja }\end{array}$ & $\begin{array}{l}32 \\
(33,4)\end{array}$ & \multirow[t]{3}{*}{$\begin{array}{l}\text { Pozitivna } \\
\text { naravnanost in } \\
\text { samozaupanje }\end{array}$} & \multirow[t]{9}{*}{$\begin{array}{l}\text { Doživljanje } \\
\text { obdobja } \\
\text { pred in v } \\
\text { menopavzi }\end{array}$} \\
\hline »Prišel je čas, ko sebe postavim na prvo mesto.» & $\begin{array}{l}\text { Posvetiti se } \\
\text { sebi }\end{array}$ & $\begin{array}{l}6 \\
(5,4) \\
\end{array}$ & & \\
\hline $\begin{array}{l}\text { "Strah pred staranjem." } \\
\text { "Res me je bilo strah, da sem resno zbolela.» }\end{array}$ & $\begin{array}{l}\text { Negotovost } \\
\text { strah, stres }\end{array}$ & $\begin{array}{l}7 \\
(7,2) \\
\end{array}$ & & \\
\hline $\begin{array}{l}\text { "Opažam, da je zelo pomembna fizična aktivnost - } \\
\text { redna." }\end{array}$ & $\begin{array}{l}\text { Telesna } \\
\text { aktivnost }\end{array}$ & $\begin{array}{l}3 \\
(3,1) \\
\end{array}$ & \multirow[t]{2}{*}{$\begin{array}{l}\text { Zdrav } \\
\text { Življenjski slog }\end{array}$} & \\
\hline $\begin{array}{l}\text { "Zavedam se, da bi še veliko lahko naredila, pri tem imam } \\
v \text { mislih rednejšo in kvalitetnejšo prehrano." } \\
\text { "Da strah preženeš, moraš izpolniti dejanja: gibanje, } \\
\text { prava prehrana." }\end{array}$ & $\begin{array}{l}\text { Uravnote-žena } \\
\text { prehrana }\end{array}$ & $\begin{array}{l}6 \\
(6)\end{array}$ & & \\
\hline $\begin{array}{l}\text { "Menim, da bi se marsikateri nevšečnosti izognili, če bi } \\
\text { dobile pravi nasvet pri ginekologinji.» }\end{array}$ & Biti poučen & $\begin{array}{l}6 \\
(5,7) \\
\end{array}$ & \multirow[t]{2}{*}{ Informiranost } & \\
\hline $\begin{array}{l}\text { "O tem obdobju sem vedela zelo malo. Šele ko sem imela } \\
\text { resne probleme, me je zdravstveno osebje začelo jemati } \\
\text { resno." }\end{array}$ & $\begin{array}{l}\text { Neprepo- } \\
\text { znavanje } \\
\text { znakov }\end{array}$ & $\begin{array}{l}2 \\
(2,9)\end{array}$ & & \\
\hline $\begin{array}{l}\text { "Pomembno je, da se o tem pogovorimo z ljudmi, ki jim } \\
\text { zaupamo.« } \\
\text { "/.../ je pomembno, da se o teh stvareh pogovarjamo.« }\end{array}$ & Pogovor & $\begin{array}{l}4 \\
(3,8)\end{array}$ & \multirow[t]{2}{*}{$\begin{array}{l}\text { Podpora } \\
\text { okolice }\end{array}$} & \\
\hline $\begin{array}{l}\text { "... imam prijateljico. } Z \text { njo sem se veliko pogovarjala in } \\
\text { prav ona mi je pomagala skozi to obdobje." } \\
\text { »ljučen je bil dober partnerski odnos ..." }\end{array}$ & Podpora & $\begin{array}{l}3 \\
(1,7)\end{array}$ & & \\
\hline
\end{tabular}

Legenda/Legend: $f$ - frekvenca/frequency; \% - odstotek/percentage 
življenjski slog, informiranost in podpora okolice), kar prikazuje Tabela 3 . V tej tabeli smo poleg pomenske razvrstitve izjav oz. kod $\mathrm{v}$ podkategorije in kategorijo prikazali primere izjav (trditev oz. besednih zvez), njihove kode in frekvenco v posamezne kode povezanih izjav. Sodelujoče so največkrat navedle, da je treba obdobje perimenopavze in menopavze jemati kot del življenja (33,4 \%), 7,2 \% žensk pravi, da to obdobje prinese skrbi, strah, negotovost, 5,4\% jih poudarja pomen znati se posvetiti sebi, $6 \%$ jih izpostavlja pomen uravnotežene prehrane, $5,7 \%$ jih izraža potrebo po poučenosti o omenjenem obdobju, $2,9 \%$ žensk ni prepoznalo znakov menopavze, 3,8 $\%$ žensk izpostavlja pomen pogovora o težavah in podpore $(1,7 \%)$ s strani bližnjih, prijateljev ter $3,1 \%$ žensk izpostavlja pomen ohranjanja telesne aktivnosti $\mathrm{v}$ tem obdobju.

\section{Diskusija}

Naša raziskava se loteva obdobja ženske, ki je lahko zanjo prijetno ali pa ji lahko povzroči kar nekaj zdravstvenih težav. Vsaka ženska to obdobje doživlja drugače, pomemben je njen odnos do sebe, do menopavze in do zdravja. Kopčavar Guček in Franić (2008) pravita, da ženske preživijo v obdobju po menopavzi kar tretjino življenja, saj se zaradi vse daljše pričakovane življenjske dobe podaljšuje tudi obdobje življenja v pomenopavzi. Čeprav ženske živijo dlje kot moški, so deležne manj let zdravega življenja, ker jih daljši čas spremljajo zdravstvene težave (Vertot, 2010). Večina anketirank svoje trenutno zdravstveno stanje ocenjuje kot dobro, večina jih je brez kroničnih obolenj. Rezultati raziskave kažejo, da se anketiranke zavedajo, da za svoje zdravje lahko veliko storijo same, večinoma se udeležujejo presejalnih preventivnih pregledov in tretjina jih je redno telesno aktivnih tudi več kot trikrat tedensko. Toda kljub temu za zdravstvene delavce na področju zdravstvene vzgoje ostaja še dovolj dela, saj se le tretjina anketiranih trudi vzdrževati ustrezno telesno težo ter le tretjina vprašanih skrbi za redno in ustrezno prehrano.

Sveinsdóttir in Ólafsson (2006) ugotavljata, da imajo islandske ženske načeloma pozitiven odnos do menopavze in menijo, da je menopavza normalen del življenja, s katerim se je treba soočiti. Rezultati naše raziskave so pokazali, da so se anketiranke najpogosteje opredelile za dejstvo, da jih žalostijo znaki staranja, mučila jih je utrujenost in izčrpanost zaradi nespečnosti, doživljale so strah pred jemanjem HNZ zaradi mogočih neželenih učinkov in izrazile so zadovoljstvo z dejstvom, da jim ni treba več skrbeti zaradi neželene nosečnosti. Tudi Črnigoj in Prosen (2016) ugotavljata, da sproščena spolnost vpliva na kakovost življenja in partnerski odnos. V raziskavi ugotavljamo, da se anketiranke, ki zaradi pogostega nihanja njihovega razpoloženja čutijo nerazumevanje okolice, o teh težavah težko pogovarjajo. Podobno ugotavljamo, da je pri tistih, ki opažajo znake staranja (suha koža, povešene prsi) - kar jih dodatno žalosti, spremenjena tudi samopodoba. Anketiranke menijo, da vedo premalo o možnostih, kako lajšati menopavzalne težave.

Anketiranke navajajo, da se jim je življenje postavilo na glavo, in menijo, da na to obdobje niso bile dovolj pripravljene. Povzamemo lahko, da anketiranke potrebujejo pogovor, izobraževanje in psihično podporo, saj se je četrtina vprašanih strinjala $\mathrm{z}$ dejstvom, da o možnostih lajšanja menopavzalnih težav sploh premalo vedo. Glede na spletno raziskavo o pogledu žensk na HNZ, alternativne terapije in spolno zdravje, ki so jo izvedli Cumming in sodelavci (2007), povzemamo podobne ugotovitve, namreč, da večina $v$ raziskavo vključenih žensk ne ve dovolj o HNZ in možnostih alternativne terapije. Zdi se, da je treba ženske informirati in osveščati na vseh nivojih zdravstvenega varstva, zlasti pa na primarnem nivoju, ki je najbolj dostopno. Podatki kažejo, da so anketiranke informacije, povezane $\mathrm{z}$ menopavzo, najpogosteje iskale $\mathrm{v}$ časopisih in revijah, na internetu in pri ginekologu. Zanimivo je dejstvo, da več kot polovica vprašanih omenjenih informacij nikoli ni iskalo pri medicinski sestri $\mathrm{v}$ ambulanti, čeprav je medicinska sestra avtonomna strokovnjakinja, katere kompetence so med drugim tudi svetovanje na področju zdravja in bolezni, promocija zdravja ter zdravstvena vzgoja (Železnik, et al., 2008). Pepić (2012) v raziskavi ugotavlja, da je bilo le 4,5\% anketirank deležnih zdravstvene vzgoje, povezane $\mathrm{z}$ menopavzo in klimakterijem, s strani ginekologa in le 2,6 \% s strani medicinske sestre. Prav tako sta do podobnih ugotovitev prišla Sveinsdóttir in Ólafsson (2006) pri islandski ženskah, in sicer primerljivost velja tako za zdravnike kot medicinske sestre. Naše anketiranke so potrdile, da so bile pridobljene informacije (iz drugih virov) zanje koristne. Eden izmed razlogov, da ženske ne želijo informacij v zdravstveni instituciji, je lahko v njihovem nepriznavanju menopavzalnih težav oziroma v skrivanju menopavzalnih simptomov (Sergeant, 2015).

Ugotavljamo, da je naša skupina anketirank $\mathrm{v}$ samooceni menopavzalnih simptomov kot največje težave izpostavila vročinske oblive, znojenje, težave $s$ spanjem ter fizično in psihično izčrpanost, nekoliko manj pa težave s srcem, motnje razpoloženja, razdražljivost in bolečine $\mathrm{v}$ mišicah in sklepih. Podatki so primerljivi s tujima raziskavama (Sveinsdóttir \& Ólafsson, 2006; Chedraui, et al., 2007), kjer so uporabili isti inštrument MRS. V raziskavah, ki so jih izvedli v Ekvadorju (Chedraui, et al., 2007) in na Islandiji (Sveinsdóttir \& Ólafsson, 2006), se je izkazalo, da so bili pri njih najpogostejši simptomi bolečine $\mathrm{v}$ mišicah in sklepih, motnje razpoloženja, spolne težave, vročinski oblivi in motnje spanja.

Brown in sodelavci (2015) so skušali raziskati psihološko stisko žensk med prehodom v menopavzo, 
vendar ugotavljajo, da je zelo malo znanega o pozitivnih izkušnjah in dobrem počutju $\mathrm{v}$ tem obdobju. Omenjajo, da pozitivna naravnanost v veliki meri vpliva na menopavzo kot odpornostni dejavnik, ki lahko ženske pripravi na izzive, ki jih prinaša obdobje srednjih let. Tudi tretjina naših anketirank je izpostavila pozitivno naravnanost do tega obdobja in do sprejemanja sprememb, izzivov in negotovosti, kar kaže na pozitiven odnos do zdravja in do spoprijemanja z znaki menopavze.

Redna telesna aktivnost kot pozitivni dejavnik pri ohranjanju zdravja in preprečevanju kroničnih nenalezljivih bolezni je bila $\mathrm{v}$ naši raziskavi $\mathrm{v}$ več kot polovici odgovorov označena $s$ pogostostjo vsaj enkrat do dvakrat tedensko, tretjina vprašanih pa je podala pogostost telesne aktivnosti tri- in večkrat tedensko. Kljub pozitivnim učinkom telesne dejavnosti na zdravje kar dve tretjini prebivalcev Evropske unije nista dovolj telesno aktivnih (Drev, 2010). Redna telesna aktivnost glede na raziskavo, ki je bila opravljena v Španiji (Villaverde-Gutierrez, et al., 2006), statistično dokazano zmanjšuje menopavzalne simptome in izboljša kakovost življenja v pomenopavzalnem obdobju, podobno navajata tudi slovenski avtorici Marn Radoš in Šćepanović, (2014). Pri oceni življenjskega sloga smo poleg življenjskih navad ocenjevali tudi razvade. Ugotovili smo, da je tretjina sodelujočih v naši raziskavi kadilk, kar je tudi evropsko povprečje (Koprivnikar, 2010). V obsežni danski študiji ugotavljajo, da se zdrav življenjski slog pomembno povezuje s samooceno zdravja (Pisinger, et al., 2009).

Glede na to, da se $\mathrm{v}$ naši raziskavi kljub visoki izobraženosti anketirank večkrat ponavlja potreba po informacijah, bi predlagali, da se aktivnosti diplomirane medicinske sestre $\mathrm{v}$ referenčni ambulanti družinske medicine razširijo tudi na področje svetovanja o menopavzi. Tudi tuje raziskave (Sveinsdóttir \& Ólafsson 2006) ugotavljajo, da bi bilo treba okrepiti svetovalno vlogo medicinske sestre. $\mathrm{V}$ tem kontekstu predlagamo vključitev mednarodnega standardiziranega vprašalnika MRS za oceno težavnosti menopavzalnih simptomov v referenčni ambulanti družinske medicine, ki se je kot primeren pokazal tudi v naši raziskavi.

Glede na omejitve naše raziskave menimo, da bi bila na temo menopavze in dostopanja do ustreznih informacij potrebna dodatna usmerjena raziskava na večjem vzorcu populacije, saj zaradi premajhnega vzorca rezultatov naše raziskave ne moremo posploševati. Vzorec vključuje anketiranke z relativno visoko stopnjo dosežene formalne izobrazbe, kar bi bilo pri naslednjem vzorčenju potrebno upoštevati.

Pri nadaljnjem raziskovanju bi predlagali kombinacijo kvantitativnega in kvalitativnega raziskovanja $\mathrm{z}$ intervjuji, kar bi omogočilo boljše razumevanje raziskanega problema. Ugotovitev izhaja iz tega, da se je na nas obrnilo nekaj anketirank, ki so izrazile željo po pogovoru.

\section{Zaključek}

Ugotavljamo, da večina anketirank svoje zdravje ocenjuje kot dobro ali zelo dobro. Anketiranke imajo pozitiven odnos do zdravja, saj v večini za svoje zdravje dobro skrbijo in imajo zdrav življenjski slog, prav tako se zavedajo, da za svoje zdravje veliko lahko storijo same.

Anketiranke $\mathrm{v}$ naši raziskavi so večkrat izrazile potrebo po informacijah, izrazile so zlasti pomanjkanje informacij, pridobljenih s strani zdravstvenih delavcev. $\mathrm{Ob}$ zaključku anketiranja so nekatere anketiranke izrazile željo pridobiti dodatne informacije o menopavzi v obliki predavanj ali izobraževalnih delavnic, saj so nas poiskale osebno ali preko telefona. Zelo je pomembno, da je ženska na to življenjsko obdobje dobro pripravljena, pozitivno naravnana in oborožena $z$ informacijami, ki jih lahko dobi iz prve roke prav pri zdravstvenih delavcih, ter ozaveščena, kaj lahko za ohranjanje svojega zdravja stori sama.

Predlagamo, da se v referenčni ambulanti družinske medicine s strani diplomirane medicinske sestre vpelje individualno svetovanje s področja menopavze, lahko pa tudi v obliki predavanj ali izobraževalnih delavnic, in sicer za ženske v starosti od 45 do 55 let. Ob tem predlagamo vključitev mednarodnega vprašalnika (MRS), vendar pa je pred tem potrebno zagotovitvi dodatno izobraževanje za diplomirane medicinske sestre in referenčne ambulante kadrovsko okrepiti.

\section{Acknowledgement/Zahvala}

The authors would like to thank the management of the Health Care Institution Revita for the approval to conduct the research. We extend our gratitude also to all the study participants./Zahvaljujemo se vodstvu Zdravstvenega zavoda Revita za dovoljenje za izvedbo raziskave, prav tako se zahvaljujemo vsem sodelujočim v raziskavi.

\section{Conflict of interest/Nasprotje interesov}

The authors declare that no conflicts of interest exist./Avtorici izjavljata, da ni nasprotja interesov.

\section{Funding/Financiranje}

The study received no funding./Raziskava ni bila finančno podprta.

\section{Ethical approval/Etika raziskovanja}

The study was conducted in accordance with the Helsinki-Tokyo Declaration (World Medical Association, 2013) and the Code of ethics for nurses and nurse assistants of Slovenia (2014). The research was approved by the management of Health institution Revita Ljubljana, where the research was conducted (the number of the approval UO - KS 1-1/14)./ 
Raziskava je pripravljena v skladu z načeli HelsinškoTokijske deklaracije (World Medical Association, 2013) in v skladu s Kodeksom etike v zdravstveni negi in oskrbi Slovenije (2014). Pridobili smo pisno dovoljenje vodstva Zdravstvenega zavoda Revita Ljubljana, kjer je bila raziskava izvedena (številka dokumenta UO - KS 1-1/14).

\section{Literature/Literatura}

Borko, E. \& Žegura, B., 2006. Menopavza. In: E. Borko \& I. Takač, eds. Ginekologija. Maribor: Univerza v Mariboru, Visoka zdravstvena šola, pp. 111-120.

British Menopause Society Council, 2011. Modernizing the NHS: observation and recommendations from the British Menopause Society. Menopause International, 17(2), pp. 41-43.

Brown, L., Bryant, C. \& Judd, F.K., 2015. Positive well-being during the menopausal transition: a systematic review. Climacteric, 18(4), pp. 456-469.

http://dx.doi.org/10.3109/13697137.2014.989827

PMid:25417543

Cencič, M., 2009. Kako poteka pedagoško raziskovanje: primer kvantitativne empirične neeksperimentalne raziskave. Ljubljana: Zavod Republike Slovenije za šolstvo, pp. 49.

Chedraui, P., Agirre, W., Hidalgo, L. \& Fayad, L., 2007. Assessing menopausal symptoms among healthy middle aged women with the Menopause Rating Scale. Maturitas, 57(3), pp. 271-278. http://dx.doi.org/10.1016/j.maturitas.2007.01.009 PMid:17329046

Cumming, G.P., Currie, H., Morris, E., Moncur, R. \& Lee A.J., 2015. The need to do better - are we still letting our patients down and at what cost? Post Reproductive Health, 21(2), pp. 56-62. http://dx.doi.org/10.1177/2053369115586122

PMid:25966991

Cumming, G.P., Herald, J., Moncur, R., Currie, H. \& Lee A.J., 2007. Women's attitudes to hormone replacement therapy, alternative therapy and sexual health: a web-based survey. Post Reproductive Health, 13(2), pp. 79-83.

http://dx.doi.org/10.1258/175404507780796424

Črnigoj, Š. \& Prosen, M., 2016. Qualitative analysis of factors associated with the experience of contraception in rural setting. Obzornik zdravstvene nege, 50(2), pp. 107-125.

http://dx.doi.org/10.14528/snr.2016.50.2.85

Drev, A., 2010. Telesna dejavnost. In: A. Hočevar Grom, ed. Zdravje $v$ Sloveniji. Ljubljana: Inštitut za varovanje zdravja Republike Slovenije, pp. 35-36.

Franić, D., 2008. Hormonske možnostizdravljenja v perimenopavzi in kasneje. Zdravniški vestnik, 77(Suppl 3), pp. 9-15.
Heinemann, K., Ruebig, A., Potthoff, P., Schneider, H., Strelow, F., Heinemann, L. \& Minh Tai, D., 2004. The Menopause Rating Scale (MRS) scale: a methodological review. Health and Quality of Life Outcomes, 45(2). Available at:

http://www.hqlo.com/content/2/1/45 [20. 7. 2015].

Hsieh, H.F. \& Shannon S.E., 2005. Three approaches to qualitative content analysis. Qualitative Health Research, 15(9), pp. $1277-1288$.

http://dx.doi.org/10.1177/1049732305276687

PMid:16204405

Kodeks etike v zdravstveni negi in oskrbi Slovenije in Kodeks etike za babice Slovenije, 2014. Ljubljana: Zbornica zdravstvene in babiške nege Slovenije - Zveza strokovnih društev medicinskih sester, babic in zdravstvenih tehnikov Slovenije.

Kopčavar Guček, N. \& Franić, D., 2008. Kakovost življenja, svetovanje in hormonsko nadomestno zdravljenje. Zdravniški vestnik, 77(Suppl 3), pp. 73-78.

Koprivnikar, H., 2010. Kajenje. In: A. Hočevar Grom, ed. Zdravje $v$ Sloveniji, Ljubljana: Inštitut za varovanje zdravja Republike Slovenije, pp. 39-40.

Labrinoudaki, I., Ceasu, I., Depypere, H., Erel, T., Rees, M., Schenck-Gustafsson, et al., 2013. EMAS position statement: Diet and health in midlife and beyond. Maturitas, 74(1), pp. 99-104.

http://dx.doi.org/10.1016/j.maturitas.2012.10.019

PMid:23200515

Lainščak, M., Fras, Z. \& Zaletel Kragelj, L., 2005. Slovenija v gibanju za zdravo prehrano. Zdravniški vestnik, 44(1), pp. 10-17.

Mander, T., 2012. Better life better health - lifestyle and diet for a healthy future. Post Reproductive Health, 18(4), pp. 123-124. http://dx.doi.org/10.1258/mi.2012.012041

Marn Radoš, M. \& Šćepanović, D., 2014. Telesna dejavnost in zdravje žensk v pomenopavzi. Obzornik zdravstvene nege, 48(4), pp. 323-331.

http://dx.doi.org/10.14528/snr.2014.48.4.35

McCloskey, C.R., 2012. Changing focus: women's perimenopausal journey. Health Care Women International, 33(6), pp. 540-559. http://dx.doi.org/10.1080/07399332.2011.610542

PMid:22577741

Meden-Vrtovec, H., 2002. Hormonsko nadomestno zdravljenje v klimakteriju. In: H. Meden-Vrtovec, ed. Zdravljenje s hormoni $v$ ginekologiji in andrologiji. Ljubljana: Klinični center, SPS Ginekološka klinika, Slovensko društvo za reproduktivno medicino, pp. 99-112.

Meden-Vrtovec, H., 2007. Ženska in moški v tretjem življenjskem obdobju. In: H. Meden-Vrtovec \& D. Franić, eds. Izbrana poglavja s področja klimakterija. Ljubljana: Arkadija, pp. 9-11. 
Mlakar, J., 2007. Psihične spremembe v obdobju po menopavzi. In: H. Meden-Vrtovec \& D. Franić, eds. Izbrana poglavja $s$ področja klimakterija. Ljubljana: Arkadija, pp. 27-33.

Pepić, J., 2012. Zdravstveno vzgojno delo v ginekološkem dispanzerju: diplomsko delo. Jesenice: Visoka šola za zdravstveno nego Jesenice, p. 33.

Petkovič, T., 2007. Kakovost življenja ženske v peri- in pomenopavzi. In: H. Meden-Vrtovec \& D. Franić, eds. Izbrana poglavja s področja klimakterija. Ljubljana: Arkadija, pp. 60-63.

Pisinger, C., Toft, U., Aadahl, M., Glümer, C. \& Jørgensen, T., 2009. The relationship between lifestyle and self-reported health in a general population: the Inter99 study. Preventive Medicine, 49, pp. 418-423.

http://dx.doi.org/10.1016/j.ypmed.2009.08.011

PMid:19716843

Sergeant, J., 2015. An exploration of women's identity during menopause: a grounded theory study: doctoral thesis. London: University of Roehampton London. Available at:

http://roehampton.openrepository.com/roehampton/ bitstream/10142/618204/3/final+approved+thesis.pdf [17. 11. 2016].

Sveinsdóttir, H. \& Ólafsson, R.F., 2006. Women's attitudes to hormone replacement therapy in the aftermath of the Women's Health Initiative study. Journal of Advanced Nursing, 54(5), pp. 572-584.

http://dx.doi.org/10.1111/j.1365-2648.2006.03862.x

PMid:16722955
Štern, B., 2007. Javno zdravje in javno zdravstvo. Zdravniški vestnik, 76(5), pp. 317-322.

Vertot, N., 2010. Starejše prebivalstvo v Sloveniji. Ljubljana: Statistični urad Republike Slovenije.

Vigeta, S.M.G., Hachul, H., Tufik, S. \& Menicucci de Olivera, E., 2012. Sleep in postmenopausal women. Qualitative Health Research, 22(4), pp. 466-475.

http://dx.doi.org/10.1177/1049732311422050

PMid:21917564

Villaverde-Gutiérrez, C., Araújo, E, Cruz, F., Roa, J.M., Barbosa, W. \& Ruíz-Villaverde, G., 2006. Quality of life of rural menopausal women in response to an exercise programme. Journal of Advanced Nursing, 54(1), pp. 11-19.

http://dx.doi.org/10.1111/j.1365-2648.2006.03784.x

PMid:16553686

World Medical Association, 2013. World Medical Association Declaration of Helsinki: ethical principles for medical research involving human subjects. Journal of the American Medical Association, 310(20), pp. 2191-2194. Available at:

http://www.wma.net/en/20activities/10ethics/10helsinki/ DoH-Oct2013-JAMA.pdf [1. 9. 2016].

Železnik, D., Brložnik, M., Buček Hajdarević, I., Dolinšek, M., Filej, B., Istenič, B., et al., 2008. Poklicne aktivnosti in kompetence $v$ zdravstveni in babiški negi. Ljubljana: Zbornica zdravstvene in babiške nege Slovenije - Zveza strokovnih društev medicinskih sester, babic in zdravstvenih tehnikov Slovenije.

\section{Cite as/Citirajte kot:}

Gregorin, J. \& Ramšak Pajk, J., 2016. Women's experience and attitudes towards menopause and health: descriptive research. Obzornik zdravstvene nege, 50(4), pp. 264-279. http://dx.doi.org/10.14528/snr.2016.50.4.119 